\title{
Severity of chronic experimental Chagas' heart disease parallels tumour necrosis factor and nitric oxide levels in the serum: models of mild and severe disease
}

\author{
Isabela Resende Pereira', Glaucia Vilar-Pereira' ${ }^{1}$, Andrea Alice da Silva ${ }^{2}$, Joseli Lannes-Vieira' ${ }^{1}{ }^{+}$ \\ ${ }^{1}$ Laboratório de Biologia das Interações, Instituto Oswaldo Cruz-Fiocruz, Rio de Janeiro, RJ, Brasil \\ ${ }^{2}$ Departamento de Patologia, Universidade Federal Fluminense, Niterói, RJ, Brasil
}

\begin{abstract}
Heart tissue inflammation, progressive fibrosis and electrocardiographic alterations occur in approximately $30 \%$ of patients infected by Trypanosoma cruzi, 10-30 years after infection. Further, plasma levels of tumour necrosis factor (TNF) and nitric oxide (NO) are associated with the degree of heart dysfunction in chronic chagasic cardiomyopathy (CCC). Thus, our aim was to establish experimental models that mimic a range of parasitological, pathological and cardiac alterations described in patients with chronic Chagas' heart disease and evaluate whether heart disease severity was associated with increased TNF and NO levels in the serum. Our results show that C3H/ He mice chronically infected with the Colombian $\mathrm{T}$. cruzi strain have more severe cardiac parasitism and inflammation than C57BL/6 mice. In addition, connexin 43 disorganisation and fibronectin deposition in the heart tissue, increased levels of creatine kinase cardiac MB isoenzyme activity in the serum and more severe electrical abnormalities were observed in T. cruzi-infected C3H/He mice compared to C57BL/6 mice. Therefore, T. cruzi-infected C3H/ He and C57BL/6 mice represent severe and mild models of CCC, respectively. Moreover, the CCC severity paralleled the TNF and NO levels in the serum. Therefore, these models are appropriate for studying the pathophysiology and biomarkers of CCC progression, as well as for testing therapeutic agents for patients with Chagas' heart disease.
\end{abstract}

Key words: Chagas disease - cardiomyopathy - experimental model - tumour necrosis factor - nitric oxide

Chagas disease (CD) is a neglected tropical disease caused by the protozoan haemoflagellate parasite Trypanosoma cruzi, which afflicts about eight million individuals in Latin America (Rassi Jr et al. 2010). In most patients, the establishment of immune response and inflammatory processes in the heart tissue are associated with parasite control and restoration of homeostasis in the acute phase of CD. However, in approximately 30\% of patients, the inflammation progresses and results in chronic chagasic cardiomyopathy (CCC), characterised by focal and diffuse inflammation, parasite persistence, myocytolysis and progressive fibrosis with remodelling of the myocardium and vasculature, which commonly results in heart failure (Laranja et al. 1956, Rassi Jr et al. 2010). Plasma levels of tumour necrosis factor (TNF) are correlated with the severity of chronic CD (PérezFuentes et al. 2003) and the degree of left ventricular dysfunction in patients with CCC (Ferreira et al. 2003, Talvani et al. 2004). During acute infection, TNF alone

doi: 10.1590/0074-0276140033

Financial support: FAPERJ (APQ1-E-26/111.756/2008, CNE/E26/101.549/2010, E-26/110.153/2013, E-26/111.709/2013), CNPq (474234/2012-6-Universal, 302534/2008-3, INCTV/CNPq, 403979/2012-9-DECIT)

$\mathrm{JL}-\mathrm{V}$ is research fellows of the CNPq.

+ Corresponding author: lannes@ioc.fiocruz.br

Received 25 January 2014

Accepted 1 April 2014 or in association with other cytokines is proposed to control of parasite replication via the release of nitric oxide (NO) by macrophages (Aliberti et al. 1999) and cardiomyocytes (Machado et al. 2000). However, the elevated TNF levels in chronic CD patients may contribute to heart tissue damage and CCC (Pérez-Fuentes et al. 2003, Lannes-Vieira et al. 2011). NO is an important cytotoxic and cytostatic factor in cell-mediated immunity to intracellular pathogens (Brunet 2001). Nevertheless, excessive NO production may cause host injury, including a reduction in myocardial contractibility (Elahi et al. 2007). Recently, inducible NO synthase (iNOS/NOS2) expression in cardiac tissue and NO overproduction were shown to be associated with the severity of heart injury and electrical abnormalities in chronically infected rhesus monkeys (Carvalho et al. 2012).

More than a century after the celebrated discovery by Chagas (1909), there are still gaps in the knowledge of CD pathophysiology. Furthermore, the therapeutic tools used to treat chronic patients only mitigate symptoms of Chagas' heart disease; therefore, new therapeutic agents are needed (Lannes-Vieira et al. 2010). In research aimed at elucidating the pathophysiology of CD or to screen potential therapeutic agents, chronic infection with T. cruzi reproduced myocarditis and fibrosis in experimentallyinfected dogs (de Lana et al. 1988), mice (Federici et al. 1964, Andrade \& Grimaud 1986), hamsters (Ramírez et al. 1994) and monkeys (Carvalho et al. 2003, 2012). Furthermore, some aspects of the electrical abnormalities associated with chronic $\mathrm{CD}$ were reproduced in rabbits (Figueiredo et al. 1986), mice (Sadigursky \& Andrade 1986, Silverio et al. 2012), dogs (Andrade et al. 1997) and 
monkeys (Rosner et al. 1989, Carvalho et al. 2003, 2012). Consider amounts of data were collected that helped to advance the knowledge of $\mathrm{CD}$ pathogenesis and to test trypanocidal drugs (Brener \& Chiari 1967, Andrade et al. 1989b). Recently, the dog model has reemerged as a potent tool for examining the pathogenesis of chronic $\mathrm{CD}$ due to the great similarity between some of the pathologies and immunological alterations common to both $\mathrm{CD}$ patients and T. cruzi-infected dogs (Guedes et al. 2009). Furthermore, rhesus monkeys replicate important cardiac and immunological aspects of Chagas' heart disease (Carvalho et al. 2003, 2012). However, the canine and non-human primate experimental models of $\mathrm{CD}$ require special facilities, are difficult to manage, expensive to keep and restricted to a few research groups. Therefore, reasonable experimental models that simultaneously reproduce relevant parasitological and clinical aspects and immunological abnormalities associated with chronic Chagas' heart disease are needed to advance the understanding of $\mathrm{CD}$ pathophysiology and the search for biomarkers of $\mathrm{CD}$ progression and to test therapeutic agents. The aim of our work was to establish realistic experimental models of varying severity that reproduce the parasitological, histopathological and clinical aspects of chronic Chagas' heart disease using two mouse lineages infected with the myotropic Colombian T. cruzi Type I strain (Federici et al. 1964, Zingales et al. 2009). Furthermore, we tested the association between the severity of heart disease and the serum TNF and NO levels of these experimental mouse models of chronic T. cruzi infection.

\section{MATERIALS AND METHODS}

Mouse models of chronic infection by T. cruzi - Five to seven-week-old female $\mathrm{C} 3 \mathrm{H} / \mathrm{He}\left(\mathrm{H}-2^{\mathrm{k}}\right)$ and $\mathrm{C} 57 \mathrm{BL} / 6$ $\left(\mathrm{H}-2^{b}\right)$ mice obtained from the animal facilities [Laboratory Animals Breeding Center, Oswaldo Cruz Foundation (Fiocruz), Rio de Janeiro, Brazil] were maintained under specific pathogen-free conditions. This study was carried out in strict accordance with the recommendations in the Guide for the Care and Use of Laboratory Animals of the Brazilian National Council of Animal Experimentation (cobea.org.br/) and the Federal Law 11.794 (8 October 2008). The institutional Committee for Animal Ethics of Fiocruz (license 004/09) approved all of the procedures used in this study.

Experimental infection - Mice were infected intraperitoneally with 100 blood trypomastigotes of the Colombian strain of $T$. cruzi, isolated from a human patient in Colombia (Federici et al. 1964) and genotypically characterised as a T. cruzi Type I strain (Zingales et al. 2009). Parasitaemia was estimated using $5 \mu \mathrm{L}$ of blood obtained from the tail vein, employed as a parameter to establish the acute and chronic phases of infection (dos Santos et al. 2001). In all sets of experiments, three-five sex and age-matched non-infected (NI) controls were analysed per time point in parallel with five-10 infected mice at 70 days post-infection (dpi), $120 \mathrm{dpi}$ or $150 \mathrm{dpi}$, according to the experimental protocol.

Reagents and antibodies - For immunohistochemistry (IHS), staining the polyclonal antibody recognising
T. cruzi antigens and the anti-mouse CD8a (53-6.7) and anti-mouse CD4 (GK1.5) supernatants were produced in our laboratory (Laboratory of Biology of the Interactions, Oswaldo Cruz Institute, Fiocruz). The anti-F4/80 polyclonal antibody recognising macrophages was purchased from Caltag (USA). The polyclonal rabbit antibody recognising connexin 43 (Cx43) was purchased from Sigma (USA). The polyclonal rabbit antibody recognising mouse fibronectin (FN) was obtained from Gibco-BRL (USA). The biotinylated anti-rat immunoglobulin was obtained from DAKO (Denmark) and the biotinylated anti-rabbit immunoglobulin and peroxidase-streptavidin complex were purchased from Amersham (England). For IHS, appropriate controls were prepared by replacing primary antibodies with rat immunoglobulin or normal rabbit serum. All antibodies and reagents were utilised in compliance with the manufacturers' instructions.

Histopathology and IHS - Groups of five-eight infected and three-five NI control mice were killed under anaesthesia at $120 \mathrm{dpi}$ or $150 \mathrm{dpi}$, according to the experimental protocols. In a series of experiments, the hearts of the mice were collected, fixed in $10 \%$ formaldehyde, processed for histopathology, embedded in paraffin and subjected to haematoxylin and eosin staining. In another set of experiments, the hearts were removed, embedded in tissue-freezing medium (Tissue-Tek, Miles Laboratories, USA) and stored in liquid nitrogen until use. Serial cryostat sections, $3 \mu \mathrm{m}$-thick, were fixed in cold acetone and subjected to indirect immunoperoxidase staining for the characterisation of inflammatory cells, as previously described (dos Santos et al. 2001). The IHS assay for detection of T. cruzi heart tissue parasitism was performed and analysed as previously described (Silverio et al. 2012). The FN and $\mathrm{Cx} 43$-positive areas in 25 fields $\left(12.5 \mathrm{~mm}^{2}\right)$ per section, in three sections per heart, were evaluated with a digital morphometric apparatus. Images were digitised using a colour view XS digital video camera adapted to a Zeiss microscope. The images were analysed with AnalySIS AUTO software (Soft Imaging System, USA). The areas that expressed the molecule of interest were integrated with the areas that did not express the molecule of interest and the data were presented as the percentage of the positive area in the heart, as the distance $(\mu \mathrm{m})$ between stained gap junctions or as parasite nests or cell numbers/100 microscopic fields (400X).

Detection of cardiac muscle creatine-kinase isoform - The activity of the creatine kinase cardiac MB isoenzyme (CK-MB) was measured using a commercial CK-MB Liquiform kit (Labtest, Brazil) in accordance with the manufacturer's recommendations and has been previously adopted for an experimental approach in a murine model of chronic infection (Medeiros et al. 2009, Silverio et al. 2012).

Electrocardiogram (ECG) registers - All mice were intraperitoneally tranquilised with diazepam $(10 \mathrm{mg} /$ $\mathrm{Kg}$ ) and transducers were carefully placed subcutaneously according to the chosen preferential derivation (DII). Two-minute long traces were recorded using the digital system Power Lab 2/20, which was connected to 
a bio-amplifier at $2 \mathrm{mV}$ for $1 \mathrm{~s}$ (PanLab Instruments, Spain). Filters were standardised to between $0.1-100 \mathrm{~Hz}$ and traces were analysed using the Scope software for Windows v.3.6.10 (PanLab Instruments, Spain). The ECG parameters were analysed as previously described (Silverio et al. 2012).

Serum TNF determination - The TNF serum concentrations were evaluated by ELISA kits for the detection of mouse TNF (R\&D Systems, USA) according to the manufacturer's protocols. The colourimetric reaction was assessed using an ELISA plate reader at $490 \mathrm{~nm}$ (ASYS Hitech GmbH, Austria). In addition, a mouse cytometric bead array (CBA Inflammation Kit, Becton \& Dickinson, USA) was used to quantify TNF in the serum according to the manufacturer's instructions. The fluorescence produced by the CBA beads was measured on a FACSCalibur (Becton Dickinson, USA) and analysed using the FCAP Array software. Standard curves (1-100 $\mathrm{ng} / \mathrm{mL}$ ) were created in parallel. These methods consistently detected concentrations above $10 \mathrm{pg} / \mathrm{mL}$.

$N O$ quantification - Nitrate and nitrite $\left(\mathrm{NO}_{\mathrm{x}}\right)$ were determined in serum samples from NI and infected mice using the Griess reagent and vanadium chloride III with a standard curve of $0.8-100 \mu \mathrm{M} \mathrm{NaNO}_{2}$ and $\mathrm{NaNO}_{3}$ (Carvalho et al. 2012).

Statistical analysis - Data are expressed as arithmetic means \pm standard deviation. Student's $t$, ANOVA or other more appropriate tests were used to analyse the statistical significance of the observed differences. The Kaplan-Meier method was used to compare the survival times of the studied groups. All statistical tests were performed using GraphPad Prism. Differences were considered statistically significant when $p<0.05$.

\section{RESULTS}

T. cruzi-infected $\mathrm{C} 3 \mathrm{H} / \mathrm{He}$ mice present higher parasitaemia, inflammation and heart parasitism than infected C57BL/6 mice - When female C57BL/6 and C3H/He mice were infected with a low inoculum of the Colombian $T$. cruzi Type I strain (Fig. 1A), circulating parasites were first detected at $14 \mathrm{dpi}$. However, the $\mathrm{C} 3 \mathrm{H} / \mathrm{He}$ animals showed higher numbers of parasites at the peak of parasitaemia, which occurs at 42-45 dpi in both mouse lineages (Fig. 1B). Furthermore, in both models of parasitaemia, control occurs from 60-70 dpi. Approximately 70-85\% of the $\mathrm{C} 57 \mathrm{BL} / 6$ and $\mathrm{C} 3 \mathrm{H} / \mathrm{He}$ mice survived (Fig. 1C) without trypanocidal treatment and developed a chronic infection when the rare blood trypomastigote was found at 90 dpi. In all surviving animals, focal and diffuse inflammatory infiltrates and remodelling of the cardiac tissue were detected in chronically infected C57BL/6 and $\mathrm{C} 3 \mathrm{H} / \mathrm{He}$ mice, compared with age-matched NI controls (Fig. 1D). The chronic myocarditis was mainly composed of $\mathrm{CD} 8^{+}, \mathrm{CD}^{+}$lymphocytes and $\mathrm{F} 4 / 80^{+}$macrophages were detected in the chronic phase of infection occurring at $120 \mathrm{dpi}$ and $150 \mathrm{dpi}$ (data not shown) in mice of both lineages, corroborating previous findings (Talvani et al. 2000, dos Santos et al. 2001, Silverio et al. 2012). Importantly, total heart inflammation, representing the sum of $\mathrm{CD}^{+}$and $\mathrm{CD}^{+} \mathrm{T}$-cell subsets and macrophages, was more pronounced in chronically $T$. cruzi-infected $\mathrm{C} 3 \mathrm{H} /$ He mice compared to infected C57BL/6 mice (Fig. 1E). Notably, heart parasitism persisted during the chronic phase of infection, being more intense in $\mathrm{C} 3 \mathrm{H} / \mathrm{He}$ mice compared to C57BL/6 mice (Fig. 1F).

Cardiac tissue injury is more severe in T. cruzi-infected C3H/He mice compared to infected C57BL/6 mice - In six-month-old NI controls, the expression of $\mathrm{Cx} 43$, a marker of cardiomyocyte connectivity (Orlic et al. 2001), was regular and organised (Fig. 2A). However, in chron-
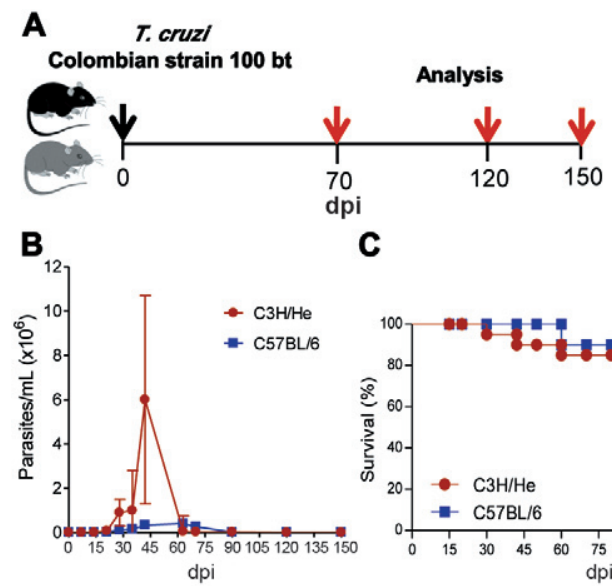

D
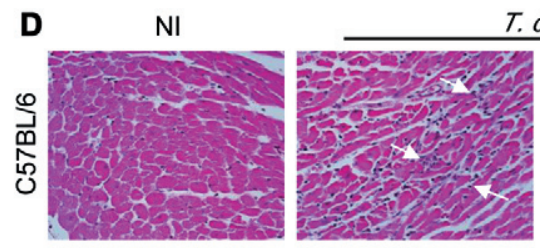

T. cruzi
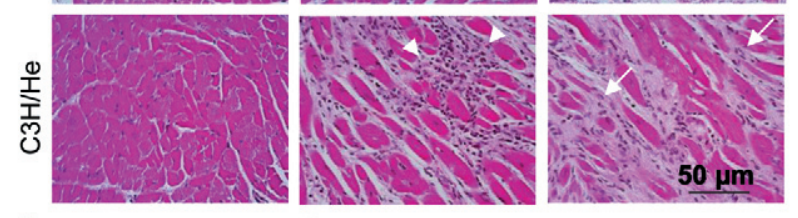

E
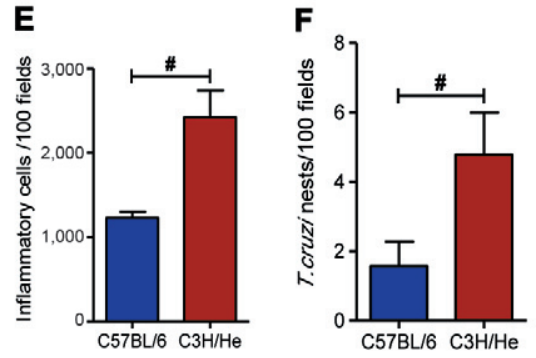

Fig. 1: Trypanosoma cruzi parasitism and inflammation persist in the heart tissue of chronically infected mice. A: experimental design of the article. C57BL/6 and $\mathrm{C} 3 \mathrm{H} / \mathrm{He}$ mice were infected with 100 blood trypomastigotes (bt) of the Colombian T. cruzi Type I strain and analysis at 70 days post-infection (dpi), $120 \mathrm{dpi}$ or $150 \mathrm{dpi}$, according experimental protocol; B: kinetics of parasitaemia; C-D: quantitative data of the immunohistochemistry for T. cruzi parasite nests (C) and total inflammatory cells (D) in the heart tissue at $120 \mathrm{dpi}$; \#: $\mathrm{p}<0.05$ C57BL/6 mice compared to $\mathrm{C} 3 \mathrm{H} / \mathrm{He}$ mice. Data obtained from three independent experiments [5 non-infected (NI) and eight-10 T. cruziinfected mice per experiment]. 
ically (150 dpi) T. cruzi-infected mice, the expression of $\mathrm{Cx} 43$ was reduced, disorganised and more disperse (Fig. $2 \mathrm{~A}$ ) and was characterised by an increased distance between the marks for $\mathrm{Cx} 43$ in the intercalated disks of the cardiomyocytes (Fig. 2B). In parallel experiments, the $\mathrm{Cx} 43$ disorganisation was increased in six-month-old NI $\mathrm{C} 3 \mathrm{H} / \mathrm{He}$ mice compared to C57BL/6 mice (Fig. 2B). Furthermore, the $\mathrm{Cx} 43$ disorganisation was more extensive in T. cruzi-infected $\mathrm{C} 3 \mathrm{H} / \mathrm{He}$ mice compared to infected C57BL/6 mice (Fig. 2B).

When compared to NI controls, increase deposition of the extracellular matrix component FN (Marino et al. 2003) was detected in the heart tissue of C57BL/6 and $\mathrm{C} 3 \mathrm{H} / \mathrm{He}$ mice infected with the Colombian $T$. cruzi strain (Fig. 3A, B). The FN expression was similar in sixmonth-old NI C57BL/6 and $\mathrm{C} 3 \mathrm{H} / \mathrm{He}$ mice, the parallel controls of the infected mice (Fig. 3B). At 150 dpi, however, the FN deposition in the cardiac tissue was more intense in $T$. cruzi-infected $\mathrm{C} 3 \mathrm{H} / \mathrm{He}$ mice compared to infected C57BL/6 mice (Fig. 3B).

CK-MB activity, which is proportional to the concen- tration of the enzyme present in the serum and assumed to be a marker of myocardial injury (Adams et al. 1993), was increased in the serum of chronically (150 dpi) $T$. cruzi-infected $\mathrm{C} 3 \mathrm{H} / \mathrm{He}$ and $\mathrm{C} 57 \mathrm{BL} / 6$ mice compared with sex and age-matched NI controls (Fig. 4). Again, the levels of CK-MB activity were elevated in the serum of T. cruzi-infected $\mathrm{C} 3 \mathrm{H} / \mathrm{He}$ mice compared to infected C57BL/6 mice (Fig. 4).

Electrocardiograph alterations are severe in $T$. cruzi-infected $\mathrm{C} 3 \mathrm{H} / \mathrm{He}$ mice - Disturbances in electrical conduction are striking features of Chagas' heart disease (Rassi Jr et al. 2010). The normal P wave and the QT complex register (Fig. 5A) were altered in chronically (150 dpi) T. cruzi-infected mice compared with sex and age-matched NI controls. Infected mice presented ECG abnormalities in the conduction system, including a prolonged $\mathrm{P}$ wave, $\mathrm{PR}$ interval and QRST complex (Fig. 5B). The duration of the QRS interval was similar in six-month-old NI C57BL/6 and $\mathrm{C} 3 \mathrm{H} / \mathrm{He}$ control mice. At $150 \mathrm{dpi}$, significant alteration of the QRS interval was detected in $T$. cruzi-infected C57BL/6 and
A
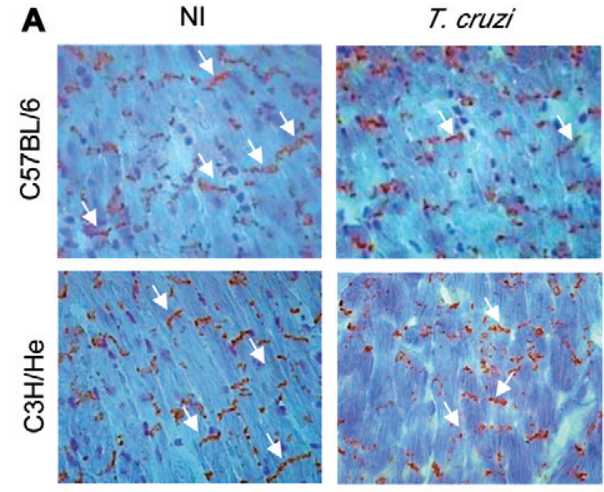

B

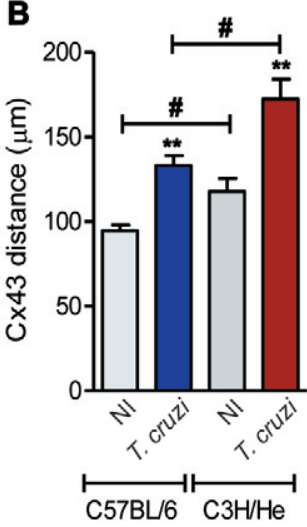

A

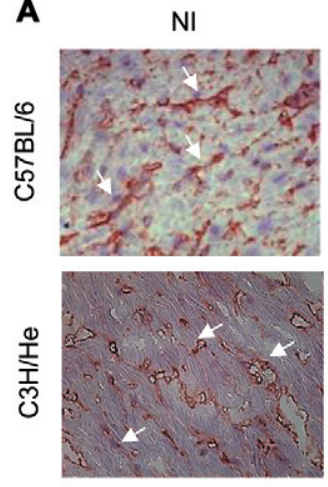

B

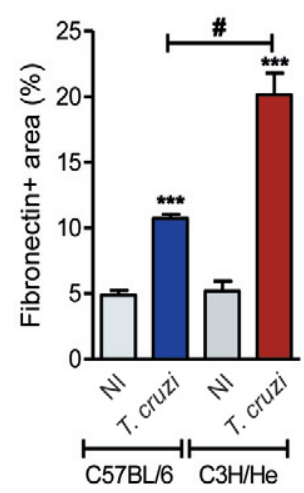

Fig. 2: Trypanosoma cruzi induces connexin 43 (Cx43) loss during the chronic phase of infection. A: representative sections of the heart tissue of non-infected (NI) and infected C57BL/6 mice analysed by immunohistochemistry for detection of $\mathrm{Cx} 43$ at 150 days post-infection; $\mathrm{B}$ : quantitative data of $\mathrm{Cx} 43$-containing gap junction distances in the heart tissue of NI and T. cruzi-infected C57BL/6 and C3H/He mice; **: $\mathrm{p}<0.01$, NI compared to T. cruzi-infected mice; \#: $\mathrm{p}<0.05$, C57BL $/ 6$ compared to $\mathrm{C} 3 \mathrm{H} / \mathrm{He}$ lineage. Data obtained from three independent experiments (5 NI and 8-10 T. cruzi-infected mice per experiment).

Fig. 3: Trypanosoma cruzi induces fibronectin (FN) deposition in the cardiac tissue during the chronic phase of infection. A: representative sections of the heart tissue of non-infected (NI) and infected C57BL/6 mice analysed by immunohistochemistry for FN deposition; B: quantitative data of FN-stained area (\%) in the heart tissue of NI and T. cruzi-infected C57BL/6 and $\mathrm{C} 3 \mathrm{H} / \mathrm{He}$ mice; ${ }^{* * *}$ : $\mathrm{p}<0.001$, NI compared to T. cruzi-infected mice; \#: $\mathrm{p}<0.05, \mathrm{C} 57 \mathrm{BL} / 6$ compared to $\mathrm{C} 3 \mathrm{H} / \mathrm{He}$ lineage. Data obtained from three independent experiments (3 NI and 5 T. cruzi-infected mice per experiment). 
$\mathrm{C} 3 \mathrm{H} / \mathrm{He}$ mice compared with their NI controls (Fig. 5C). Additionally, the prolonged QRS interval was more pronounced in infected $\mathrm{C} 3 \mathrm{H} / \mathrm{He}$ mice compared to $\mathrm{C} 57 \mathrm{BL} / 6$ mice $(\mathrm{p}<0.01)$. In both mouse lineages, T. cruzi-infected mice frequently show ECG alterations such as arrhythmias (ARTs) and a second-degree atrioventricular block (AVB2). Moreover, a low frequency of infected $\mathrm{C} 3 \mathrm{H} /$ $\mathrm{He}$ and $\mathrm{C} 57 \mathrm{BL} / 6$ mice also presented with an AVB1, while fibrillation was rarely $(<5 \%)$ detected in infected mice of either lineage. Therefore, T. cruzi-infected mice frequently $(80 \%$ for $\mathrm{C} 57 \mathrm{BL} / 6$ and $100 \%$ for $\mathrm{C} 3 \mathrm{H} /$ He) showed ECG abnormalities (Fig. 5D). Altogether, the ECG abnormalities were more frequent and severe in $T$. cruzi-infected $\mathrm{C} 3 \mathrm{H} / \mathrm{He}$ mice compared to infected C57BL/6 mice.

High TNF and NO levels are detected in the serum of Colombian-infected $\mathrm{C} 3 \mathrm{H} / \mathrm{He}$ and C57BL/6 mice - Compared with six-month-old matched NI controls, the serum TNF levels of chronically (150 dpi) T. cruzi-infected $\mathrm{C} 57 \mathrm{BL} / 6$ and $\mathrm{C} 3 \mathrm{H} / \mathrm{He}$ mice were significantly increased (Fig. 6). Moreover, while the slight increase in the TNF levels in the serum of $\mathrm{NI} \mathrm{C3H/He} \mathrm{mice} \mathrm{compared} \mathrm{to} \mathrm{NI}$ C57BL/6 mice was not significant ( $p>0.05)$, the TNF levels were eight-12-fold higher in T. cruzi-infected $\mathrm{C} 3 \mathrm{H} / \mathrm{He}$ mice compared to infected C57BL/6 mice ( $\mathrm{p}<$ 0.05) (Fig. 6).

Considering that $\mathrm{NO}$ is proposed to control T. cruzi growth during acute infection (Silva et al. 2003), we measured the serum nitrate $/ \mathrm{NO}_{\mathrm{x}}$ concentrations of mice after parasitaemia control, which occurs at 60-70 dpi (Fig. 1B). At 70 dpi, $\mathrm{NO}_{\mathrm{x}}$ levels were increased in the serum of infected mice of either lineage in comparison with their NI sex and age-matched controls (Fig. 7). Furthermore, the $\mathrm{NO}_{\mathrm{x}}$ levels in the serum of T. cruzi-infected $\mathrm{C} 3 \mathrm{H} / \mathrm{He}$ mice were higher than in the serum of infected C57BL/6 mice (Fig. 7).

The severity of cardiac tissue injury and ECG abnor-

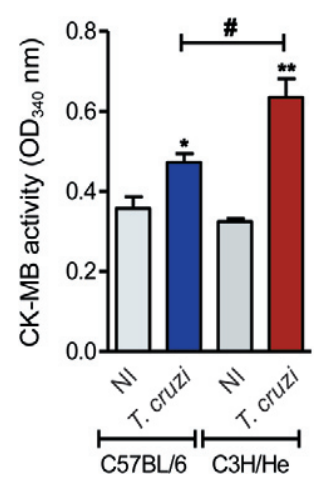

Fig. 4: Trypanosoma cruzi induces cardiomyocyte lesion during the chronic phase of infection. Enzymatic evaluation of creatine kinase cardiac MB isoenzyme (CK-MB) activity in the serum of non-infected (NI) and T. cruzi-infected $\mathrm{C} 57 \mathrm{BL} / 6$ and $\mathrm{C} 3 \mathrm{H} / \mathrm{He}$ mice at 150 days post-infection. Data obtained from three independent experiments (3-5 NI and 6-8 T. cruzi-infected mice per experiment). OD: optical density; *: p < $0.05 ; * *: \mathrm{p}<0.01$, NI compared to T. cruzi-infected mice; \#: $\mathrm{p}<0.05$, $\mathrm{C} 57 \mathrm{BL} / 6$ compared to $\mathrm{C} 3 \mathrm{H} / \mathrm{He}$ lineage. malities parallels the TNF and NO levels in the serum during T. cruzi infection - Finally, all the analysed parameters were comparatively scored for each of the four groups studied (NI and T. cruzi-infected C57BL/6 and $\mathrm{C} 3 \mathrm{H} / \mathrm{He}$ mice). As summarised in Table, analysis of the different markers of heart injury and electrical abnor-
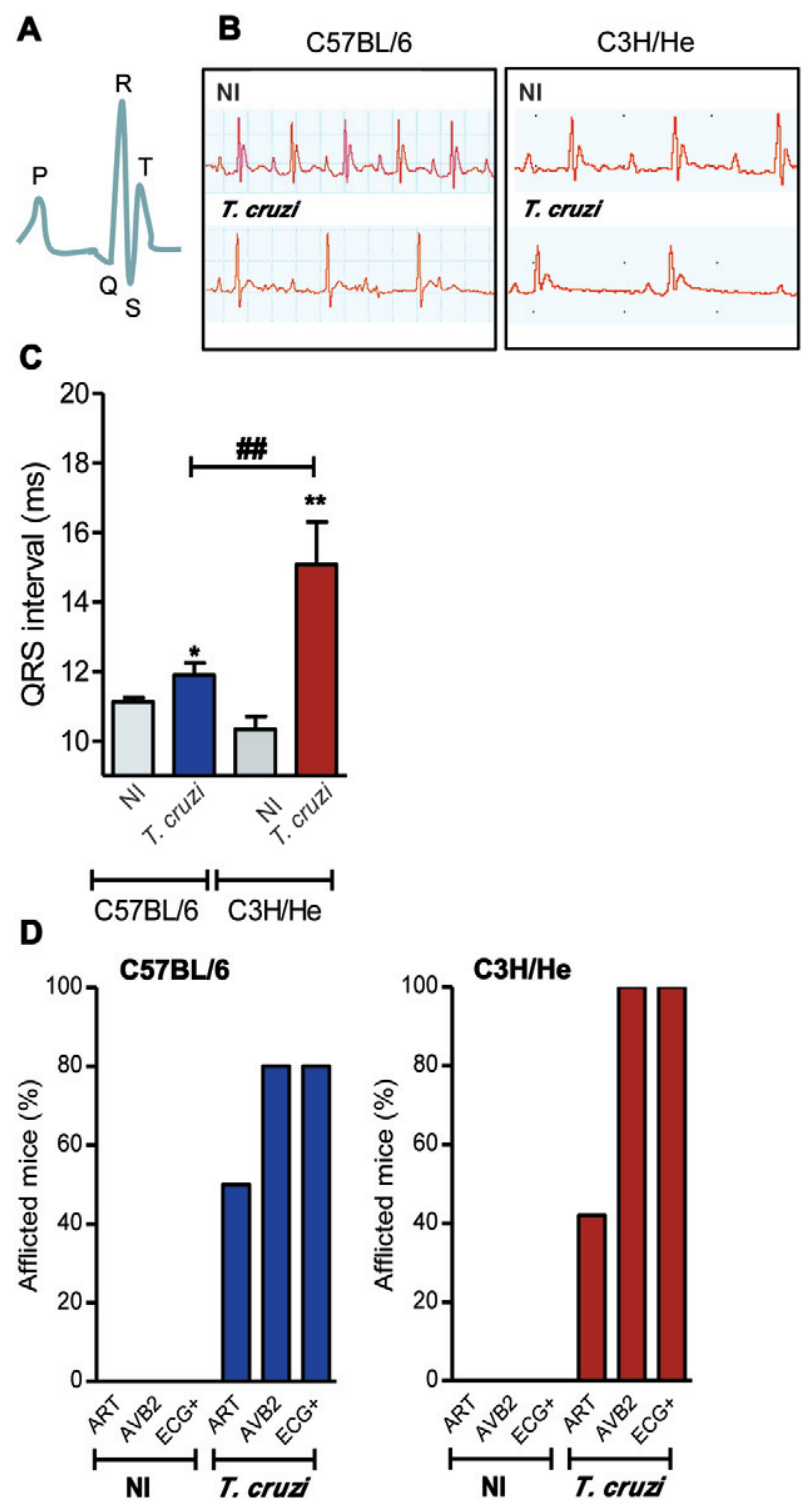

Fig. 5: Trypanosoma cruzi induces electrocardiographic (ECG) abnormalities during the chronic phase of infection. A: schematic representation of the P wave and QT complex segment of the ECG register of a non-infected (NI) mice; B: representative ECG register segments of sex and age-matched NI controls and T. cruzi-infected $\mathrm{C} 3 \mathrm{H} / \mathrm{He}$ mice at 150 days post-infection; $\mathrm{C}$ : data for ECG records showing the duration (ms) of the QRS interval; D: summary of the group data for the frequency of NI and $T$. cruzi-infected mice presenting arrhythmias (ARTs), second-degree atrioventricular block (AVB2) and total ECG alterations; **: $\mathrm{p}<0.01$, NI compared to T. cruzi-infected mice; \#: $\mathrm{p}<0.05, \mathrm{C} 57 \mathrm{BL} / 6$ compared to $\mathrm{C} 3 \mathrm{H} / \mathrm{He}$ lineage. Data obtained from three independent experiments (5 NI and 8-10 T. cruzi-infected mice per experiment). 
malities during the chronic T. cruzi infection revealed that these alterations are more intense in $\mathrm{C} 3 \mathrm{H} / \mathrm{He}$ mice compared with C57BL/6 mice. Importantly, the intensity of chronic heart tissue injury and severity of ECG abnormalities paralleled the TNF and $\mathrm{NO}_{\mathrm{x}}$ levels in the serum of infected $\mathrm{C} 57 \mathrm{BL} / 6$ and $\mathrm{C} 3 \mathrm{H} / \mathrm{He}$ mice (Table).

\section{DISCUSSION}

In the present study, we propose two reasonable experimental models with differing degrees of $T$. cruziinduced chronic cardiomyopathy that are supported by parasitological, histopathological, biochemical and electrocardiographic findings. Furthermore, we show that the severity of experimental Chagas' heart disease parallels the TNF and NO levels in the serum. Thus, these models reproduce, for the first time, the parallelism between the clinical severity and two relevant immunological features described in chronic cardiopathic CD patients.

The search for a suitable experimental animal model that reproduces the parasitological and clinical aspects of $\mathrm{CD}$ was initiated soon after the discovery of the disease (Chagas 1909, Torres \& Villaça 1919). Although several studies were carried out using different animal models that reproduce aspects of the chronic disease (Laranja et al. 1956, Federici et al. 1964, Andrade \& Grimaud 1986, Figueiredo et al. 1986, Sadigursky \& Andrade 1986, de Lana et al. 1988, Rosner et al. 1989, Ramírez et al. 1994, Andrade et al. 1997, Carvalho et al. 2003, 2012, Silverio et al. 2012), reasonable experimental models that simultaneously reproduce relevant parasitological and clinical aspects of the chronic Chagas' heart disease in association with immunological abnormalities are still needed.

In trying to prove a causal relationship of the parasite strain to the heart disease, Federici et al. (1964) used a $T$. cruzi strain (Colombian) isolated from a human patient in Colombia and the inbred $\mathrm{C} 3 \mathrm{H} / \mathrm{He}$ mouse lineage. In this study, parasitaemia peak occurred after $30 \mathrm{dpi}$ and parasite control occurred by $60 \mathrm{dpi}$, as corroborated by
C57BL/6

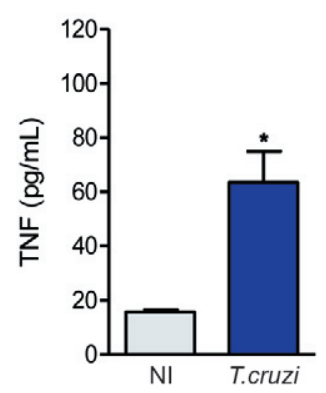

$\mathrm{C} 3 \mathrm{H} / \mathrm{He}$

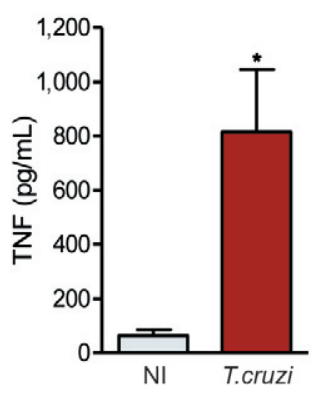

Fig. 6: Trypanosoma cruzi induces increased tumour necrosis factor (TNF) levels during the chronic phase of infection. Detection of TNF concentrations in the serum of non-infected (NI) and T. cruzi-infected $\mathrm{C} 57 \mathrm{BL} / 6$ and $\mathrm{C} 3 \mathrm{H} / \mathrm{He}$ mice. Representative data obtained from two independent experiments using ELISA and CBA Inflammation Kit (3 NI and 5 T. cruzi-infected mice per experiment). *: p $<0.05$, NI compared to $T$. cruzi-infected mice. our results. Furthermore, loss of cardiomyocytes and replacement by fibrosis in the presence of focal necrosis and inflammation was observed during chronic infection (Federici et al. 1964), resembling features of Chagas' heart disease (Higuchi et al. 2003). Later, the model of Colombian-infected $\mathrm{C} 3 \mathrm{H} / \mathrm{He}$ mice was shown to reproduce the CD8-enriched chronic T. cruzi-induced myocarditis (dos Santos et al. 2001) and was used to study the cellular and molecular mechanisms of heart tissue colonisation by inflammatory cells (Marino et al. 2004, Kroll-Palhares et al. 2008, Medeiros et al. 2009). The infection of C57BL/6 mice with the Colombian strain also reproduces the CD8-enriched chronic myocarditis (Talvani et al. 2000), as well as important aspects of the CD electrocardiographic abnormalities (Silverio et al. 2012). This collection of data showed that $\mathrm{C} 3 \mathrm{H} / \mathrm{He}$ and $\mathrm{C} 57 \mathrm{~B} / 6$ mice infected by the Colombian strain reproduce relevant features of CCC. However, studies comparing these models with regards to the features of CCC such as parasitism, inflammation, biomarkers of heart injury and electrical abnormalities were not previously performed. Furthermore, a study of immunological mediators associated with CCC in prior studies (Ferreira et al. 2003, Pérez-Fuentes et al. 2003, Talvani et al. 2004, Carvalho et al. 2012) was also missing in these models. Mice of the $\mathrm{C} 57 \mathrm{BL} / 6$ and $\mathrm{C} 3 \mathrm{H} / \mathrm{He}$ lineages infected with a low inoculum of the Colombian strain survived the acute phase and developed chronic infections with persistent heart parasitism and low grade $\mathrm{CD} 8^{+} \mathrm{T}$-cell-enriched inflammation, corroborating previous findings (Talvani et al. 2000, dos Santos et al. 2001, Medeiros et al. 2009, Silverio et al. 2012). Moreover, experiments performed in parallel showed that $\mathrm{C} 3 \mathrm{H} / \mathrm{He}$ mice were more susceptible to the acute phase, with higher parasitaemia. However, mice of both lineages similarly survived and developed chronic infections, although $\mathrm{C} 3 \mathrm{H} / \mathrm{He}$ mice presented higher cardiac parasitism and inflammation than their C57BL/6 counterparts.

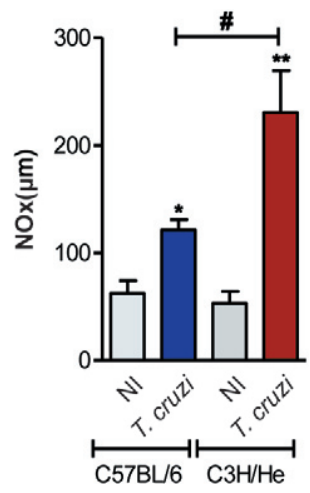

Fig. 7: Trypanosoma cruzi infection increased nitric oxide (NO) levels in the serum. Concentrations of nitrate/nitrite were measured in the serum of non-infected (NI) and T. cruzi-infected C57BL/6 and $\mathrm{C} 3 \mathrm{H} /$ $\mathrm{He}$ mice at 70 days post-infection, using modified Griess methodology. Data obtained from three independent experiments (3 NI and 3-5 T. cruzi-infected mice per experiment). *: $\mathrm{p}<0.05 ; * *: \mathrm{p}<0.01$, NI compared to T. cruzi-infected mice; \#: $\mathrm{p}<0.05$, C57BL/6 compared to $\mathrm{C} 3 \mathrm{H} / \mathrm{He}$ lineage. 
Next, we used biomarkers of heart injury to compare the extent of the tissue lesions in the $\mathrm{C} 3 \mathrm{H} / \mathrm{He}$ and C57BL/6 models of chronic T. cruzi infection. An intense $\mathrm{Cx} 43$ disorganisation in the heart tissue was detected in chronically infected $\mathrm{C} 3 \mathrm{H} / \mathrm{He}$ and $\mathrm{C} 57 \mathrm{BL} / 6$ mice compared with their NI controls. Furthermore, infected mice showed distinguishable degrees of $\mathrm{Cx} 43$ disorganisation, which was more intense in the $\mathrm{C} 3 \mathrm{H} / \mathrm{He}$ lineage compared to $\mathrm{C} 57 \mathrm{BL} / 6$ mice. Previous data showed that acute $T$. cruzi infection induces $\mathrm{Cx} 43$ disorganisation and remodelling, with delocalisation of the connexin plaques from the intercalated discs and lateralisation (Kroll-Palhares et al. 2008, Adesse et al. 2011). The Cx43 lateralisation accompanies electrical alterations in myocardial infarction and heart failure (Duffy 2012). Moreover, there is an association between disorganisation and loss of $\mathrm{Cx} 43$, the most abundant ventricular gap junction protein and arrhythmogenic diseases (Orlic et al. 2001). Importantly, $\mathrm{Cx} 43$ expression is down regulated in patients with CCC (Waghabi et al. 2009) and chronically T. cruzi-infected monkeys (Carvalho et al. 2012), supporting the conservation of this feature in different species subjected to $T$. cruzi infection. Thus, both experimental murine models used in our study reproduce this relevant aspect of CCC.

Chagas' heart disease may be considered a progressive fibrotic disorder (Higuchi et al. 2003). Enhanced deposition of extracellular matrix components, including FN, characterises the cardiac tissue fibrosis that develops during chronic T. cruzi infection in mice (Andrade et al. 1989a, dos Santos et al. 2001) and patients (Higuchi et al. 1999). Furthermore, a higher frequency of CD patients with heart failure present severe fibrosis, myocarditis and myocardial hypertrophy compared to

TABLE

Comparative study of cardiac and immunological alterations in Trypanosoma cruzi-infected C57BL/6 and $\mathrm{C} 3 \mathrm{H} / \mathrm{He}$ mice

\begin{tabular}{lcccccc}
\hline & \multicolumn{2}{c}{ C57BL/6 } & & \multicolumn{2}{c}{ C3H/He } \\
\cline { 2 - 3 } \cline { 5 - 6 } Parameters & NI & T. cruzi & & NI & T. cruzi \\
\hline Parasitism $^{a}$ & - & & + & & - & +++ \\
Inflammation $^{a}$ & - & + & & - & +++ \\
Cx43 loss $^{a}$ & + & +++ & & ++ & ++++ \\
FN deposition $^{a}$ & + & & ++ & & + & ++++ \\
CK-MB activity $^{b}$ & + & & ++ & & + & +++ \\
ECG alterations & - & & ++ & & - & +++ \\
TNF $^{b}$ & + & +++ & & ++ & +++++ \\
NO $^{b}$ & + & & & & + & +++ \\
\hline
\end{tabular}

$a$ : analysis of the heart tissue; $b$ : analysis of biomarkers in the serum; CK-MB: creatine kinase cardiac MB isoenzyme; Cx43: connexin 43; ECG: electrocardiogram; FN: fibronectin; NI: non-infected; NO: nitric oxide; TNF: tumour necrosis factor; -: no detection of the analysed parameter; +: scores based on the relative expression of the analysed parameter comparing the four groups of mice. indeterminate-form patients (Higuchi et al. 1987). Our studies showed for the first time that it was possible to discriminate between experimental models of chronic T. cruzi infection having intense $(\mathrm{C} 3 \mathrm{H} / \mathrm{He})$ and slight (C57BL/6) FN deposition, which paralleled the degree of heart inflammation and therefore resembled CD patients (Higuchi et al. 1987). Although FN expression was down regulated in $T$. cruzi-bearing cardiomyocytes in vitro (Calvet et al. 2004), the presence of the parasite and its antigens triggered the production of $\mathrm{FN}$ in skeletal muscle cells (Pinho et al. 2002, Marino et al. 2003). In benznidazole-treated mice, reduced heart parasitism is accompanied by decreased FN deposition and fibrosis (Andrade et al. 1991), supporting a parallelism between heart parasitism and FN expression. Furthermore, FN promotes T. cruzi adhesion to and uptake by macrophages and fibroblasts (Ouaissi et al. 1985, Noisin \& Villalta 1989) and may perpetuate heart parasitism. In this context, the differential degree of FN deposition detected in the heart tissue of $\mathrm{C} 3 \mathrm{H} / \mathrm{He}$ and $\mathrm{C} 57 \mathrm{BL} / 6$ mice paralleled the intensity of heart parasitism and may reflect a causal relationship. This idea deserves to be explored.

Serum CK-MB activity is an important non-invasive biomarker of cardiomyocyte lesions in both acute (de Souza et al. 2000, Kroll-Palhares et al. 2008) and chronic (Medeiros et al. 2009, Carvalho et al. 2012) experimental chagasic cardiomyopathy. In our current findings, the intensity of the cardiomyocyte lesion, as revealed by increased levels of serum CK-MB activity, is more severe in infected $\mathrm{C} 3 \mathrm{H} / \mathrm{He}$ compared to $\mathrm{C} 57 \mathrm{BL} / 6$ mice and is related to the degree of inflammation, FN deposition and $\mathrm{Cx} 43$ disorganisation in the heart tissue. Additionally, our data reinforce the applicability of CK-MB activity as a biomarker for distinguishing between degrees of heart tissue damage in chronic T. cruzi infection.

Both $\mathrm{C} 3 \mathrm{H} / \mathrm{He}$ and $\mathrm{C} 57 \mathrm{BL} / 6 \mathrm{CCC}$ models reproduced the ECG abnormalities, primarily ARTs and first and second-degree AVBs, detected in chronically T. cruziinfected patients (Rassi Jr et al. 2010). Furthermore, a prolonged QRS interval was detected in chronically Colombian-infected C57BL/6 and $\mathrm{C} 3 \mathrm{H} / \mathrm{He}$ mice compared with their NI controls. Interestingly, the QRS score directly correlates with cardiac fibrosis, as revealed by magnetic resonance myocardial scar size and inversely correlated with left ventricular ejection fraction in chronic chagasic patients (Strauss et al. 2011). Furthermore, in Colombian-infected rhesus monkeys with CCC, the intensity of fibrosis has been shown to be related to the severity of electrical abnormalities (Carvalho et al. 2012). When comparing chronically infected C57BL/6 and $\mathrm{C} 3 \mathrm{H} / \mathrm{He}$ mice, the severity of the ECG abnormalities, particularly regarding the prolonged QRS intervals, was directly related to the extent of FN deposition and Cx43 disorganisation in heart tissue and levels of CKMB activity in the serum. Therefore, the non-invasive ECG register should be further explored and validated as a tool reflecting the magnitude of myocardial scar in Chagas' heart disease, as proposed by Strauss et al. (2011) and supported by our data. Moreover, the Colombianinfected $\mathrm{C} 3 \mathrm{H} / \mathrm{He}$ and $\mathrm{C} 57 \mathrm{BL} / 6$ models may increase the understanding of the pathophysiological causal relation- 
ship between myocardial scar and ECG alterations.

There is a consensus that CD is a multifactorial disorder, in which T. cruzi persistence and parasite-driven deregulated immune responses are key players in the establishment of CCC (Lannes-Vieira et al. 2009). Serum TNF levels correlated with CD severity (Pérez-Fuentes et al. 2003) and the degree of cardiac dysfunction in patients with CCC (Ferreira et al. 2003, Talvani et al. 2004). Chronically T. cruzi-infected $\mathrm{C} 57 \mathrm{BL} / 6$ and $\mathrm{C} 3 \mathrm{H} / \mathrm{He}$ mice have increased expression of TNF mRNA and protein in the heart tissue (Talvani et al. 2000, dos Santos et al. 2001, Medeiros et al. 2009). Importantly, we show that $\mathrm{C} 57 \mathrm{BL} / 6$ and $\mathrm{C} 3 \mathrm{H} / \mathrm{He}$ mice present a range of TNF levels in the serum paralleling the intensities of cardiac tissue injury and ECG abnormalities and thus mimicking features of CD patients with different degrees of CCC severity (Ferreira et al. 2003, Talvani et al. 2004). Increased TNF concentrations can directly damage myocardial cells and may be responsible for the pathogenesis of advanced heart failure (Feldman \& McNamara 2000). In T. cruzi infection, experiments using an anti-TNF blocking antibody have implicated TNF as trigger of parasite-induced acute heart injury characterised by $\mathrm{Cx} 43$ disorganisation, increased serum CK-MB activity (Kroll-Palhares et al. 2008) and chronic CD8-enriched myocarditis (Pérez et al. 2009). Altogether, these data reinforce the importance of the Colombian-infected C57BL/6 and $\mathrm{C} 3 \mathrm{H} / \mathrm{He}$ mouse models for the further exploration of the pathophysiological role of TNF in CCC.

According to Pérez-Fuentes et al. (2003), the pathophysiology of $\mathrm{CD}$ is associated with enhanced TNF and NO production. Furthermore, high NO levels in the serum are associated with the severity of heart injury and electrical and echocardiographic alterations in chronically infected rhesus monkeys (Carvalho et al. 2012). Infection with $T$. cruzi, especially occurring in a cytokine-enriched milieu, induces NO expression by macrophages and cardiomyocytes (Aliberti et al. 1999, Machado et al. 2000). However, the molecular mechanisms leading to exacerbated NO production in $\mathrm{CD}$ are not fully understood. In acute infection, NO plays a beneficial role as trypanocidal agent (Silva et al. 2003). Conversely, NO overproduction via iNOS/NOS2 activity has been implicated in heart injury in $T$. cruzi-infected mon-

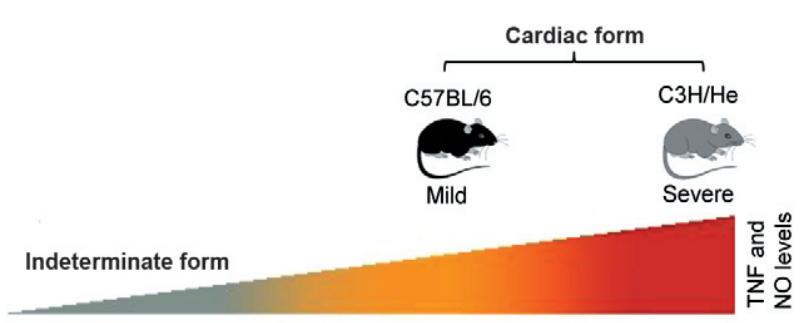

Severity of chronic Chagas disease

Fig. 8: schematic synthesis of the proposal of experimental models for chronic chagasic cardiomyopathy reproducing the mild (C57BL/6) and severe $(\mathrm{C} 3 \mathrm{H} / \mathrm{He})$ manifestations of Chagas' heart disease in association with tumour necrosis factor (TNF) and nitric oxide (NO) levels in the serum. keys and mice (Carvalho et al. 2012). Indeed, high NO concentrations may be detrimental in $T$. cruzi infection by depressing lymphocyte functions, which could favour parasite survival and promoting heart denervation and myocardial cell dysfunction (Silva et al. 2003, PérezFuentes et al. 2007). Interestingly, our data support that T. cruzi-infected $\mathrm{C} 3 \mathrm{H} / \mathrm{He}$ mice present higher serum $\mathrm{NO}$ concentrations than $\mathrm{C} 57 \mathrm{BL} / 6$ mice, paralleling the severity of heart injury and electrical abnormalities.

The pathophysiology of Chagas' heart disease is not fully understood. Previous studies did not ignore the influence of host factors, but supported the importance of the parasite strain as a crucial factor in determining cardiac lesions in mice, particularly with regards to a biological Type III strain (Andrade 1990) that is currently viewed as the genotypic T. cruzi Type I strain (Zingales et al. 2009). Our study highlights a potential contribution of the immune response, as illustrated by the variable degrees of TNF and NO production in the Colombianinfected $\mathrm{C} 57 \mathrm{BL} / 6$ and $\mathrm{C} 3 \mathrm{H} / \mathrm{He}$ mice, as determinant of $\mathrm{CCC}$ severity and therefore supporting the influence of host factors in the fate of Chagas' heart disease. However, the cause/consequence relationship between TNF and NO levels in the serum and heart tissue lesion and ECG alterations is not settled. Furthermore, events surrounding the induction of elevated TNF and NO levels in the serum of chronically T. cruzi-infected individuals remain to be identified. One cannot rule out the possibility that enhanced levels of TNF and NO and cardiac damage are all consequences of a more severe acute phase in animals of the $\mathrm{C} 3 \mathrm{H} / \mathrm{He}$ lineage compared to $\mathrm{C} 57 \mathrm{BL} / 6$ mice. If this is true, high levels of TNF and NO would not lead to a more severe pathology, but would rather be a consequence of the more severe pathology in the chronic infection. These ideas deserve to be experimentally challenged.

Altogether, cardiac tissue parasitism and inflammation, heart injury and ECG abnormalities were less intense in the chronically Colombian-infected C57BL/6 compared to $\mathrm{C} 3 \mathrm{H} / \mathrm{He}$ mice, suggesting that they represent models of mild $(\mathrm{C} 57 \mathrm{BL} / 6)$ and severe $(\mathrm{C} 3 \mathrm{H} / \mathrm{He})$ CCC. Moreover, in these models the CCC severity paralleled TNF and NO levels in the serum (Fig. 8). Therefore, these reasonable experimental models open a window of opportunity to (i) study the pathophysiology of CD and biomarkers of CCC progression and (ii) test therapeutic agents for patients with Chagas' heart disease.

\section{ACKNOWLEDGEMENTS}

To Dr Jaline Silverio (veterinary doctor) and Nathalia Vinagre, for helping, respectively, with the ECG acquirement and IHS of the first experiment, to Raquel Martins and Dr Carmem Penido, for helping with the CBA for TNF detection, to Dr Silvia Martins Marinho, for the revision of the ECG results, and to Mrs Leonardo Ruivo, for helping with the figures.

\section{REFERENCES}

Adams JE, Abendschein DR, Jaffe AS 1993. Biochemical markers of myocardial injury. Is MB creatine kinase the choice for the 1990s? Circulation 88: 750-763.

Adesse D, Goldenberg RC, Fortes FS, Jasmin, Iacobas DA, Iacobas S, de Carvalho AC, Meirelles MN, Huang H, Soares MB, Tanowitz 
HB, Garzoni LR, Spray DC 2011. Gap junctions and Chagas disease. Adv Parasitol 76: 63-81.

Aliberti JC, Machado FS, Souto JT, Campanelli AP, Teixeira MM, Gazzinelli RT, Silva JS 1999. $\beta$-chemokines enhance parasite uptake and promote nitric oxide-dependent microbiostatic activity in murine inflammatory macrophages infected with Trypanosoma cruzi. Infect Immun 67: 4819-4826.

Andrade SG 1990. Influence of Trypanosoma cruzi strain on the pathogenesis of chronic myocardiopathy in mice. Mem Inst Oswaldo Cruz 85: 17-27.

Andrade SG, Grimaud JA 1986. Chronic murine myocarditis due to Trypanosoma cruzi - an ultrastructural study and immunochemical characterization of cardiac interstitial matrix. Mem Inst Oswaldo Cruz 81: 29-41.

Andrade SG, Grimaud JA, Stocker-Guerret S 1989a. Sequential changes of the connective matrix components of the Myocardium (fibronectin and laminin) and evolution of cardiac fibrosis in mice infected with Trypanosoma cruzi. Am J Trop Med Hyg 40: $252-260$.

Andrade SG, Magalhães JB, Pontes AL 1989b. Therapy of the chronic phase of the experimental infection by Trypanosoma cruzi with benzonidazole and nifurtimox. Rev Soc Bras Med Trop 22: 113-118.

Andrade SG, Stocker-Guerret S, Pimentel AS, Grimaud JA 1991. Reversibility of cardiac fibrosis in mice chronically infected with Trypanosoma cruzi under specific chemotherapy. Mem Inst Oswaldo Cruz 86: 187-200.

Andrade ZA, Andrade SG, Sadigursky M, Wenthold Jr RJ, Hilbert SL, Ferrans VJ 1997. The indeterminate phase of Chagas disease: ultrastructural characterization of cardiac changes in the canine model. Am J Trop Med Hyg 57: 328-336.

Brener Z, Chiari E 1967. Susceptibility of different strains of Trypanosoma cruzi to various chemotherapeutic agents. Rev Inst Med Trop Sao Paulo 9: 197-207.

Brunet LR 2001. Nitric oxide in parasitic infections. Int Immunopharmacol 1: 1457-1467.

Calvet CM, Meuser M, Almeida D, Meirelles MN, Pereira MC 2004. Trypanosoma cruzi-cardiomyocyte interaction: role of fibronectin in the recognition process and extracellular matrix expression in vitro and in vivo. Exp Parasitol 107: 20-30.

Carvalho CM, Silverio JC, da Silva AA, Pereira IR, Coelho JM, Britto CC, Moreira OC, Marchevsky RS, Xavier SS, Gazzinelli RT, Bonecini-Almeida MG, Lannes-Vieira J 2012. Inducible nitric oxide synthase in heart tissue and nitric oxide in serum of Trypanosoma cruzi-infected rhesus monkeys: association with heart injury. PLoS Negl Trop Dis 6: e1644.

Carvalho CME, Andrade MCR, Xavier SS, Mangia RHR, Britto CC, Jansen AM, Fernandes O, Lannes-Vieira J, Bonecini-Almeida MG 2003. Chronic Chagas disease in rhesus monkeys (Macaca mulatta): evaluation of parasitemia, serology, electrocardiography, echocardiography and radiology. Am J Trop Med Hyg 68: 683-691.

Chagas C 1909. Nova tripanozomiaze humana. Estudos sobre a morfolojia e o ciclo evolutivo do Schizotrypanum cruzi n. gen., n. sp., ajente etiolojico de nova entidade morbida do homem. Mem Inst Oswaldo Cruz 1: 159-218.

de Lana M, Tafuri WL, Caliari MV, Bambirra EA, Chiari CA, Leite VH, Barbosa AJ, Toledo MJ, Chiari E 1988. Chronic fibrotic cardiac stage of experimental trypanosomiasis cruzi in dogs. Rev Soc Bras Med Trop 21: 113-121. de Souza AP, Olivieri BP, de Castro SL, de Araújo-Jorge TC 2000. Enzymatic markers of heart lesion in mice infected with Trypanosoma cruzi and submitted to benznidazole chemotherapy. Parasitol Res 86: 800-808.

dos Santos PVA, Roffê E, Santiago HC, Torres RA, Marino APMP, Paiva CN, Silva AA, Gazzinelli RT, Lannes-Vieira J 2001. Prevalence of CD8(+)alpha beta $\mathrm{T}$ cells in Trypanosoma cruzi-elicited myocarditis is associated with acquisition of CD62L Low LFA-1${ }^{\text {High }}$ VLA- ${ }^{\text {High }}$ activation phenotype and expression of IFN-gamma-inducible adhesion and chemoattractant molecules. Microbes Infect 3: 971-984.

Duffy HS 2012. The molecular mechanisms of gap junction remodeling. Heart Rhythm 9: 1331-1334.

Elahi M, Asopa S, Matata B 2007. NO-cGMP and TNF-alpha counter regulatory system in blood: understanding the mechanisms leading to myocardial dysfunction and failure. Biochim Biophys Acta 1772: 5-14

Federici EE, Abelmann WH, Neva FA 1964. Chronic and progressive myocarditis and myositis in $\mathrm{C} 3 \mathrm{H}$ mice infected with Trypanosoma cruzi. Am J Trop Med Hyg 13: 272-280.

Feldman AM, McNamara D 2000. Myocarditis. N Engl J Med 343: 1388-1398.

Ferreira RC, Ianni BM, Abel LCJ, Buck P, Mady C, Kalil J, CunhaNeto E 2003. Increased plasma levels of tumor necrosis factor- $\alpha$ in asymptomatic/"indeterminate" and Chagas disease cardiomyopathy patients. Mem Inst Oswaldo Cruz 98: 407-411.

Figueiredo F, Marin-Neto JA, Rossi MA 1986. The evolution of experimental Trypanosoma cruzi cardiomyopathy in rabbits: further parasitological, morphological and functional studies. Int $J$ Cardiol 10: 277-290.

Guedes PM, Veloso VM, Afonso LC, Caliari MV, Carneiro CM, Diniz LF, Marques-da-Silva EA, Caldas IS, Matta MAV, Souza SM, Lana M, Chiari E, Galvão LM, Bahia MT 2009. Development of chronic cardiomyopathy in canine Chagas disease correlates with high IFN- $\gamma$, TNF- $\alpha$ and low IL-10 production during the acute infection phase. Vet Immunol Immunopathol 130: 43-52.

Higuchi ML, Benvenuti LA, Reis MM, Metzger M 2003. Pathophysiology of the heart in Chagas disease: current status and new developments. Cardiovasc Res 60: 96-107.

Higuchi ML, de Morais CF, Barreto ACP, Lopes EA, Stolf N, Bellotti G, Pileggi F 1987. The role of active myocarditis in the development of heart failure in chronic Chagas disease: a study based on endomyocardial biopsies. Clin Cardiol 10: 665-670.

Higuchi ML, Fukasawa S, de Brito T, Parzianello LC, Bellotti G, Ramires JA 1999. Different microcirculatory and interstitial matrix patterns in idiopathic dilated cardiomyopathy and Chagas disease: a three dimensional confocal microscopy study. Heart 82: 279-285.

Kroll-Palhares K, Silverio JC, da Silva AA, Michailowsky V, Marino AP, Silva NM, Carvalho CME, Pinto LMO, Gazzinelli RT, Lannes-Vieira J 2008. TNF/TNFR1 signaling up-regulates CCR5 expression by $\mathrm{CD}^{+} \mathrm{T}$ lymphocytes and promotes heart tissue damage during Trypanosoma cruzi infection: beneficial effects of TNF- $\alpha$ blockade. Mem Inst Oswaldo Cruz 103: 375-385

Lannes-Vieira J, de Araújo-Jorge TC, Soeiro MN, Gadelha P, CorrêaOliveira R 2010. The centennial of the discovery of Chagas disease: facing the current challenges. PLoS Negl Trop Dis 4: e645.

Lannes-Vieira J, Pereira IR, Vinagre NF, Arnez LE 2011. TNF- $\alpha$ and TNFR in Chagas disease: from protective immunity to pathogenesis of chronic cardiomyopathy. Adv Exp Med Biol 691: 221-230.

Lannes-Vieira J, Silverio JC, Pereira IR, Vinagre NF, Carvalho CME, Paiva CN, da Silva AA 2009. Chronic Trypanosoma cruzi-elicited cardiomyopathy: from the discovery to the proposal of rational 
therapeutic interventions targeting cell adhesion molecules and chemokine receptors - how to make a dream come true. Mem Inst Oswaldo Cruz 104 (Suppl. I): 226-235.

Laranja FS, Dias E, Miranda A, Nobrega G 1956. Chagas disease: a clinical, epidemiologic and pathologic study. Circulation 14: 1035-1060.

Machado FS, Martins GA, Aliberti JC, Mestriner FL, Cunha FQ, Silva JS 2000. Trypanosoma cruzi-infected cardiomyocytes produce chemokines and cytokines that trigger potent nitric oxidedependent trypanocidal activity. Circulation 102: 3003-3008.

Marino AP, da Silva A, dos Santos P, Pinto LM, Gazzinelli RT, Teixeira MM, Lannes-Vieira J 2004. Regulated on activation, normal T cell expressed and secreted (RANTES) antagonist (MetRANTES) controls the early phase of Trypanosoma cruzi-elicited myocarditis. Circulation 110: 1443-1449.

Marino AP, Silva AA, Pinho RT, Lannes-Vieira J 2003. Trypanosoma cruzi infection: a continuous invader-host cell cross talk with participation of extracellular matrix and adhesion and chemoattractant molecules. Braz J Med Biol Res 36: 1121-1133.

Medeiros GA, Silvério JC, Marino AP, Roffê E, Vieira V, Kroll-Palhares K, Carvalho CE, Silva AA, Teixeira MM, Lannes-Vieira J 2009. Treatment of chronically Trypanosoma cruzi-infected mice with a CCR1/CCR5 antagonist (Met-RANTES) results in amelioration of cardiac tissue damage. Microbes Infect 11: 264-273.

Noisin EL, Villalta F 1989. Fibronectin increases Trypanosoma cruzi amastigote binding to and uptake by murine macrophages and human monocytes. Infect Immun 57: 1030-1034.

Orlic D, Kajstura J, Chimenti S, Jakoniuk I, Anderson SM, Li B, Pickel J, McKay R, Nadal-Ginard B, Bodine DM, Leri A, Anversa P 2001. Bone marrow cells regenerate infarcted myocardium. $\mathrm{Na}$ ture 410: 701-705.

Ouaissi MA, Cornette J, Capron A 1985. Trypanosoma cruzi: modulation of parasite-cell interaction by plasma fibronectin. Eur $J$ Immunol 15: 1096-1101.

Pérez AR, Fontanella GH, Nocito AL, Revelli S, Bottasso O 2009. A short treatment with the tumour necrosis factor-alpha blocker infliximab diminishes chronic chagasic myocarditis in rats without evidence of Trypanosoma cruzi reactivation. Clin Exp Immunol 157: 291-299.

Pérez-Fuentes R, Guégan JF, Barnabé C, López-Colombo A, SalgadoRosas H, Torres-Rasgado E, Briones B, Romero-Díaz M, RamosJiménez J, Sánchez-Guillén MC 2003. Severity of chronic Chagas disease is associated with cytokine/antioxidant imbalance in chronically infected individuals. Int J Parasitol 33: 293-299.

Pérez-Fuentes R, López-Colombo A, Ordóñez-Toquero G, GomezAlbino I, Ramos J, Torres-Rasgado E, Salgado-Rosas H, RomeroDíaz M, Pulido-Pérez P, Sánchez-Guillén MC 2007. Correlation of the serum concentrations of tumour necrosis factor and nitric oxide with disease severity in chronic Chagas disease (American trypanosomiasis). Ann Trop Med Parasitol 101: 123-132.

Pinho RT, Vannier-Santos MA, Alves CR, Marino AP, Branco LRC, Lannes-Vieira J 2002. Effect of Trypanosoma cruzi released antigens binding to non-infected cells on anti-parasite antibody recognition and expression of extracellular matrix components. Acta Trop 83: 103-115.

Ramírez LE, Lages-Silva E, Soares Jr JM, Chapadeiro E 1994. The hamster (Mesocricetus auratus) as experimental model in Chagas disease: parasitological and histopathological studies in acute and chronic phases of Trypanosoma cruzi infection. Rev Soc Bras Med Trop 27: 163-169.

Rassi Jr A, Rassi A, Marin-Neto JA 2010. Chagas disease. Lancet 375: 1388-1402.

Rosner IM, Bellasai J, Schinini A, Rovira T, de Arias AR, Ferro EA, Ferreira E, Velazquez G, Monzón MI, Maldonado M, Galeano R, Fresco MA 1989. Cardiomyopathy in Cebus apella monkeys experimentally infected with Trypanosoma cruzi. Trop Med Parasitol 40: 24-31.

Sadigursky M, Andrade SG 1986. Electrocardiographic changes in experimental chronic murine Chagas disease. Braz J Med Biol Res 19: 379-388.

Silva JS, Machado FS, Martins GA 2003. The role of nitric oxide in the pathogenesis of Chagas disease. Front Biosci 8: 314-325.

Silverio JC, Pereira IR, Cipitelli MC, Vinagre NF, Rodrigues MM, Gazzinelli RT, Lannes-Vieira J 2012. CD8 ${ }^{+}$T-cells expressing interferon gamma or perforin play antagonistic roles in heart injury in experimental Trypanosoma cruzi-elicited cardiomyopathy. PLoS Pathog 8: e1002645.

Strauss DG, Cardoso S, Lima JA, Rochitte CE, Wu KC 2011. ECG scar quantification correlates with cardiac magnetic resonance scar size and prognostic factors in Chagas disease. Heart 97: 357-361.

Talvani A, Ribeiro CS, Aliberti JC, Michailowsky V, Santos PV, Murta SM, Romanha AJ, Almeida IC, Farber J, Lannes-Vieira J, Silva JS, Gazzinelli RT 2000. Kinetics of cytokine gene expression in experimental chagasic cardiomyopathy: tissue parasitism and endogenous IFN-gamma as important determinants of chemokine mRNA expression during infection with Trypanosoma cruzi. Microbes Infect 2: 851-866.

Talvani A, Rocha MO, Ribeiro AL, Correa-Oliveira R, Teixeira MM 2004. Chemokine receptor expression on the surface of peripheral blood mononuclear cells in Chagas disease. J Infect Dis 189: 214-220.

Torres M, Villaça J 1919. Encefalite e mielite causados por um Tripanozomo (T. cruzi). Mem Inst Oswaldo Cruz 11: 80-89.

Waghabi MC, Coutinho-Silva R, Feige J-J, Higuchi ML, Becker D, Burnstock G, de Araújo-Jorge TC 2009. Gap junction reduction in cardiomyocytes following transforming growth factor- $\beta$ treatment and Trypanosoma cruzi infection. Mem Inst Oswaldo Cruz 104: 1083-1090.

Zingales B, Andrade SG, Briones MRS, Campbell DA, Chiari E, Fernandes $\mathrm{O}$, Guhl F, Lages-Silva E, Macedo AM, Machado CR, Miles MA, Romanha AJ, Sturm NR, Tibayrenc M, Schijman AG 2009. A new consensus for Trypanosoma cruzi intraspecific nomenclature: second revision meeting recommends $\mathrm{TcI}$ to $\mathrm{TcVI}$. Mem Inst Oswaldo Cruz 104: 1051-1054. 